\title{
Delphinidin and cyanidin exhibit antiproliferative and apoptotic effects in MCF7 human breast cancer cells
}

\author{
Jessica Tang ${ }^{1,2 *}$, Emin Oroudjev ${ }^{1}$, Leslie Wilson ${ }^{1}$ and George Ayoub ${ }^{1}$ \\ ${ }^{1}$ Department of Molecular, Cellular \& Developmental Biology, University of California, Santa Barbara, USA \\ ${ }^{2}$ School of Medicine, Medical Sciences, Indiana University, Bloomington, USA
}

\begin{abstract}
Fruits high in antioxidants such as berries and pomegranates have been shown to have many biological effects, including anticancer activity. We previously reported that bilberry (European blueberry) extract exhibited cytotoxic effects on MCF7-GFP-Tubulin breast cancer cells. To delve further into the mechanism of action of bilberry extract, we focused on two of the most abundant anthocyanins found in bilberry, delphinidin and cyanidin. In this study, we examined the radical scavenging activity, antiproliferative, and apoptotic effects of delphinidin and cyanidin on MCF7 breast cancer cells in comparison to Trolox, a vitamin E analog. DPPH radical scavenging activity assay showed at $50 \%$ antioxidant activity, an $\mathrm{IC}_{50}$ of $80 \mu \mathrm{M}, 63 \mu \mathrm{M}, 1.30 \mu \mathrm{M}$ for delphinidin, cyanidin, and Trolox, respectively. As determined by SRB assay, delphinidin, cyanidin, and Trolox were shown to inhibit MCF7 cell proliferation at IC of $_{50} 20 \mathrm{M}, 47.18 \mu \mathrm{M}$, and $11.25 \mu \mathrm{M}$, respectively. Immunofluorescence revealed that delphinidin, cyanidin, and Trolox caused apoptotic features such as rounding up of cell, retraction of pseudopodes, condensation of chromatin, minor modification of cytoplasmic organelles, and plasma membrane blebbing. Together, these results show that delphinidin and cyanidin have significant radical scavenging activity, inhibit cell proliferation, and increase apoptosis of MCF7 breast cancer cells.
\end{abstract}

\section{Introduction}

Total amount of anthocyanins and oxygen radical absorbing capacity of four Vaccinium species was measured and blueberries were found to be one of the richest sources of antioxidant phytonutrients [1]. Bilberry (Vaccinium myrtillus) contains several anthocyanidins, cyanidin, which is found in highest quantity, delphinidin and petunidin found in quantities 2.5 fold lower than cyanidin, and malvidin and peonidin [2].

A public interest is growing in the health advantages of using phytoceuticals such as anthocyanins in replacement of synthetic compounds used in chemotherapeutic or chemopreventive action $[3,4]$. Numerous anticancer effects from anthocyanins include cytotoxicity [5], antioxidation [6-12], anti-inflammation [13], cell cycle perturbations[14], active oxygen radical scavenging effect [11,15], lipid peroxidation [16], antiproliferation [5,17-19], epidermal growth factor receptor inhibition [20], and apoptosis [21-24]. In addition, pycnogenol, a preparation derived from pine bark, which contains high amounts of procyanidins, selectively induces death in human mammary cancer cells (derived from human fibrocystic mammary tissue) but not in normal human mammary MCF-10 cells [25].

Recently, we have demonstrated inhibition of proliferation, cell cycle arrest, and apoptosis-like cytotoxicity of MCF7 human breast cancer cells by bilberry extract [26]. Due to their abundance in bilberry, delphinidin and cyanidin were examined for their radical scavenging ability, antiproliferative effects, and apoptosis inducing effect in MCF7 cells. In addition, delphinidin and cyanidin are compared to Trolox, a vitamin E analog to be used as a reference compound for antioxidant capacity. DPPH radical scavenging assay, sulforhodamine B proliferation assay, and immunocytochemistry assay are used to examine the anticancer effects of delphinidin, cyanidin, and Trolox on MCF7 cells.

\section{Materials and methods}

\section{Materials}

All the chemicals and reagents used in this experiment were purchased from Sigma-Aldrich (St. Louis, MO, U.S.A) unless otherwise specified. Cyanidin chloride and delphinidin chloride were dissolved by adding $30.98 \mu \mathrm{l}$ and $29.52 \mu \mathrm{l}$ dimethylsulphoxide (DMSO) to $1 \mathrm{mg}$ anthocyanidin, respectively, obtaining $100 \mathrm{mM}$ stock concentration. Trolox (6-Hydroxy-2,5,7,8-tetramethyl-2-carboxylic acid) was purchased from Calbiochem (San Diego, CA, U.S.A.).

\section{Cell culture}

Human Caucasian breast adenocarcinoma (MCF7) cells from American Type Culture Collection, Rockville, MD, U.S.A., were grown in Dulbecco's Modified Eagle's medium (DMEM) supplemented with $10 \%$ fetal bovine serum (Atlanta Biological, Atlanta, GA, U.S.A.), L-glutamine, MEM nonessential amino acid solution, sodium bicarbonate, and penicillin $\mathrm{G}(100 \mathrm{U} / \mathrm{mL})$, streptomycin $(100 \mu \mathrm{g} / \mathrm{mL})$, at $37^{\circ} \mathrm{C}$ in a humidified atmosphere containing $95 \%$ air and $5 \% \mathrm{CO}_{2}$ [27]. Culture media were changed every 3-4 days and doubling time was $36 \mathrm{~h}$.

\section{DPPH radical scavenging capacity (anti-oxidation) assay}

Free radical scavenging activity of delphinidin, cyanidin, and

Correspondence to: Jessica Tang, $\mathrm{PhD}$, School of Medicine, Medical Sciences, Indiana University, Bloomington, IN47405, USA; E-mail: jesstang@indiana.edu Key words: anthocyanin, bilberry extract, breast cancer, apoptosis, tubulin damage Received: January 20, 2015; Accepted: February 07, 2015; Published: February 09,2015 
Trolox (Calbiochem) were compared to each other by reaction with DPPH (2,2-diphenyl-1-picryhydrazyl) radical. DPPH (SigmaAldrich) was dissolved in methanol to a final concentration of $4 \mathrm{mg} /$ $\mathrm{ml}$. A dilution series of concentrations for cyanidin and delphinidin were made starting at $500 \mu \mathrm{M}$ in DMSO. Trolox was made at $20 \mu \mathrm{M}$ in ethanol. Delphinidin, cyanidin, and Trolox diluted solutions were placed in 96-well microtiter plate. $100 \mu \mathrm{L}$ DPPH stock solution diluted 1:20 in ethanol was delivered to each well and let stand in dark room. Optical density of all wells measured at $490 \mathrm{~nm}\left(\mathrm{OD}_{490}\right)$ with microplate reader before and after DPPH addition. Absorbance values of the reaction solution were measured spectrophotometrically at $490 \mathrm{~nm}$ at $30 \mathrm{~min}$ and converted into the percentage antioxidant activity (AA) using the following formula:

$$
\mathrm{AA} \%=100-\left\{\left[\left(\mathrm{Abs}_{\text {sample }}-\mathrm{Abs}_{\text {blank }}\right) \times 100\right] / \mathrm{Abs}_{\text {control }}\right\}
$$

DPPH solution and ethanol was used as negative control. A plot of $\%$ AA vs. concentration was made to establish the standard curve and calculate $\mathrm{IC}_{50}$ values using linear correlation formula.

\section{Sulforhodamine B(SRB) cell proliferation assay}

MCF7 cells were seeded at a density of $2 \times 10^{5} / \mathrm{mL}(0.1 \mathrm{~mL}$ per well) in 96-well microtiter plates and allowed to attach for 24 hours before treatment. Delphinidin, cyanidin, and Trolox were serially diluted beginning at $1000 \mu \mathrm{M}, 250 \mu \mathrm{M}$, and $20 \mu \mathrm{M}$, respectively, in DMEM supplemented with $10 \%$ fetal bovine serum (final concentrations of ethanol were at or below 1.4\%). Preliminary experiments (data not shown) were conducted to determine dose ranges. When $1.4 \%$ of $70 \%$ ethanol alone was added to the vehicle control wells, it did not affect proliferation of the cells. After incubation for $72 \mathrm{hr}$, cells were fixed with $10 \%$ (wt./vol.) trichloroacetic acid and stained with $0.4 \%$ SRB solution for $30 \mathrm{~min}$, after which excess dye was removed by washing repeatedly with $1 \%$ (wt./vol.) acetic acid. The dye was eluted with Tris buffer and quantified photometrically at $490 \mathrm{~nm}$. The percentage of growth inhibition was calculated as:

$$
\left(\mathrm{OD}_{\text {highest concentration }} \mathrm{x} 100\right) / \mathrm{OD}_{\text {lowest concentration }}
$$

\section{Immunofluorescence microscopy}

MCF7-GFP-Tubulin cells were grown on a cover glass slip in a 6-well plate and treated with delphinidin, cyanidin, and Trolox at concentrations beginning at $100 \mu \mathrm{M}, 250 \mu \mathrm{M}$, and $20 \mu \mathrm{M}$, respectively, for 24 hours. Immunofluorescence microscopy of actin, tubulin, and DNA staining were performed for cyanidin and Trolox drugged MCF7 cells, whereas delphinidin treated MCF7 cells were only stained for DNA and tubulin. Cells were fixed in 3.7\% formaldehyde and stained with rabbit monoclonal antibody- $\alpha$-tubulin (1:500) in $0.5 \%$ BSA-PBS or Alexa488- $\alpha$-rabbit (1:300) in 1.0\% BSA, followed by addition of FITCconjugated anti-mouse secondary antibody to stain the microtubules and by rhodamine-conjugated phalloidin (Invitrogen, Carlsbad, CA) to stain actin filaments. Cells were mounted to the microscope slides with 40, 6-diamidino-2-phenylindolec-ontaining ProLong Gold with DAPI medium (Invitrogen). Microscopy was performed on a spinning disk confocal microscope (model IX81 DSU, Olympus, Tokyo, Japan). Images were acquired with an ImagEM camera (Hamamatsu, Shizuoka, Japan) under the control of SlideBook software (Olympus).

\section{Statistics}

Results are reported as average values of at least three independent experiments. Means of individual groups were converted to a percentage of the control value and expressed as the mean \pm SE.

\section{Results \\ DPPH free radical scavenging assay}

The free radical scavenging capability of delphinidin and cyanidin was compared with the scavenging effects of Trolox, a reference standard antioxidant, by DPPH antioxidant assay. Concentrations of cyanidin and delphinidin $(500 \mu \mathrm{M})$ were approximated to predetermined, comparable Trolox concentrations $(20 \mu \mathrm{M})$ in order to determine whether the anticancer effects are purely an antioxidant effect or some other specialized mechanism of action. Delphinidin and cyanidin were capable of scavenging DPPH radicals in a concentrationdependent manner as compared to control. After 30 minutes of incubation with $\mathrm{DPPH}$, absorbance values were measured and $\mathrm{IC}_{50}$ values were calculated using linear correlation of antioxidant activity percentages. The $\mathrm{IC}_{50}$ for delphinidin, cyanidin, and Trolox were 80 $\mu \mathrm{M}, 63 \mu \mathrm{M}$, and $1.30 \mu \mathrm{M}$, respectively (Figure 1 ).

\section{Sulforhodamine B colorimetric cytotoxicity assay}

MCF7 cells were treated with delphinidin, cyanidin, and Trolox that was serially diluted beginning at $1000 \mu \mathrm{M}, 250 \mu \mathrm{M}$, and $20 \mu \mathrm{M}$, respectively. Treatment of delphinidin, cyanidin, and Trolox exhibited a concentration-dependent inhibition of growth of MCF7 cells after a $24 \mathrm{hr}$ incubation period. The $\mathrm{IC}_{50}$ values for delphinidin, cyanidin, and Trolox were $120 \mu \mathrm{M}, 47.18 \mu \mathrm{M}$, and $11.25 \mu \mathrm{M}$, respectively (Figure 2). Trolox was more effective at DPPH radical scavenging. At the low concentrations of $1 \mu \mathrm{M}$ and even $0.1 \mu \mathrm{M}$ Trolox, $40 \%$ of MCF7 cell growth was inhibited.

\section{Immunofluorescence microscopy}

MCF7-GFP-Tubulin cells were treated with delphinidin, cyanidin, and Trolox at concentrations beginning at $100 \mu \mathrm{M}, 125 \mu \mathrm{M}$, and 20 $\mu \mathrm{M}$, respectively, for 24 hours. Delphinidin, cyanidin, and Trolox were all capable of morphologically damaging MCF7 cells to a certain degree as determined by DAPI, tubulin and actin fluorescence microscopy. Control MCF7 cells showed round and evenly stained nuclei with intact tubulin and actin polymers that were fully extended from the nucleus (Figure 3A,3E,3I). At $24 \mathrm{hr}$ of $50 \mu \mathrm{M}$ delphinidin treatment, rounding-up of cells and detachment from substrate is observed plus aggregated tubulin and chromatin condensation (Figure 3B). At 75 $\mu \mathrm{M}$ and $100 \mu \mathrm{M}$ delphinidin, the majority of cells were either dead or detached, but the cells that were on the path to dying reveals retraction of pseudopodes, chromatin condensation, and tubulin aggregation (Figure 3C,3D). At $24 \mathrm{hr}$ of $62.5 \mu \mathrm{M}, 125 \mu \mathrm{M}$ and $250 \mu \mathrm{M}$ cyanidin treatment, there is rounding-up of cells, chromatin condensation, and plasma membrane blebbing in a dose-dependent manner as seen by the heavily fragmented tubulin and actin microfilaments (Figure 3F,G,H). At the lowest concentration $1.25 \mu \mathrm{M}$ Trolox, only some MCF7 cells had apoptotic features and if so, were less drastic than at the higher concentrations (Figure 3J). At $5 \mu \mathrm{M}$ and $20 \mu \mathrm{M}$ treatment with Trolox, there was retraction of pseudopods, damaged plasma membrane, and chromatin condensation (Figure $3 \mathrm{~K}, 3 \mathrm{~L}$ ). At $\mathrm{IC}_{50}=11.25 \mu \mathrm{M}$ Trolox, classic apoptotic characteristics were seen in the MCF7 cells. These cells were rounded up and hadchromatin condensation with plasma membrane blebbing. The cytological damage for delphinidin, cyanidin, and Trolox coincides with our approximate $\mathrm{IC}_{50}$ seen in SRB antiproliferation assays.

\section{Discussion}

We have previously reported that bilberry extract inhibits cell proliferation and induces apoptosis in MCF7 cells [26]. In this study, 


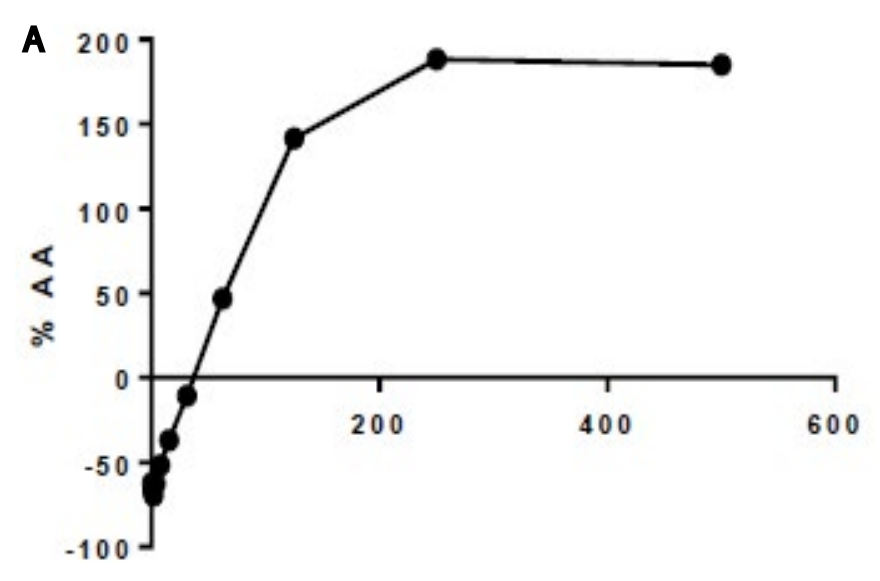

Concentration ( $u M)$ C y anidin



Concentration ( $u M$ ) Delphinidin

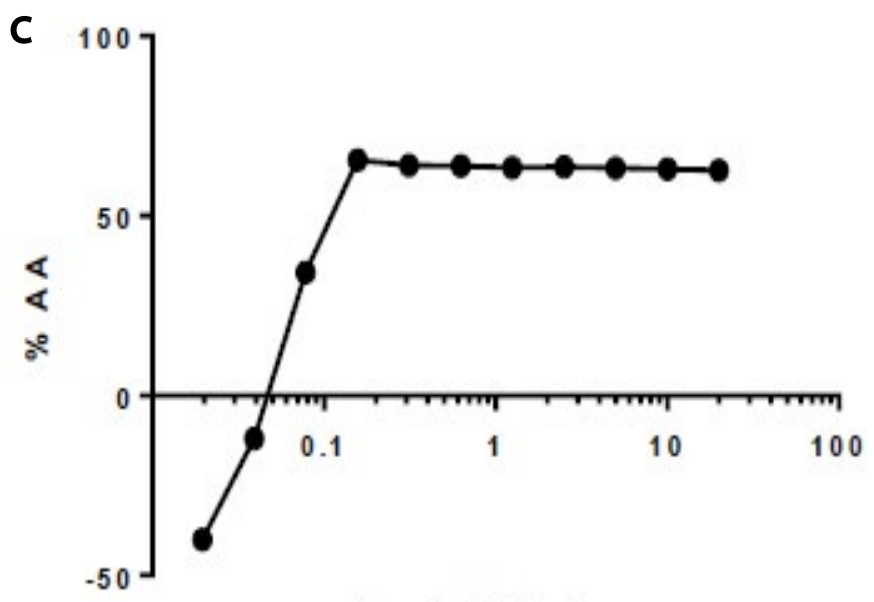

$\log (u M)$ Trolox

Figure 1. Radical scavenging activity of delphinidin, cyanidin, and Trolox. DPPH free radicals.

were allowed to scavenge varying concentrations of (A) Delphinidin, (B) Cyanidin, and (C) Trolox for $30 \mathrm{~min}$. Percentage of antioxidant activity (AA\%) was determined. At $30 \mathrm{~min}$, the $\mathrm{IC}_{50}$ for delphinidin, cyanidin, and Trolox were $80 \mu \mathrm{M}, 63 \mu \mathrm{M}, 1.30 \mu \mathrm{M}$, respectively.
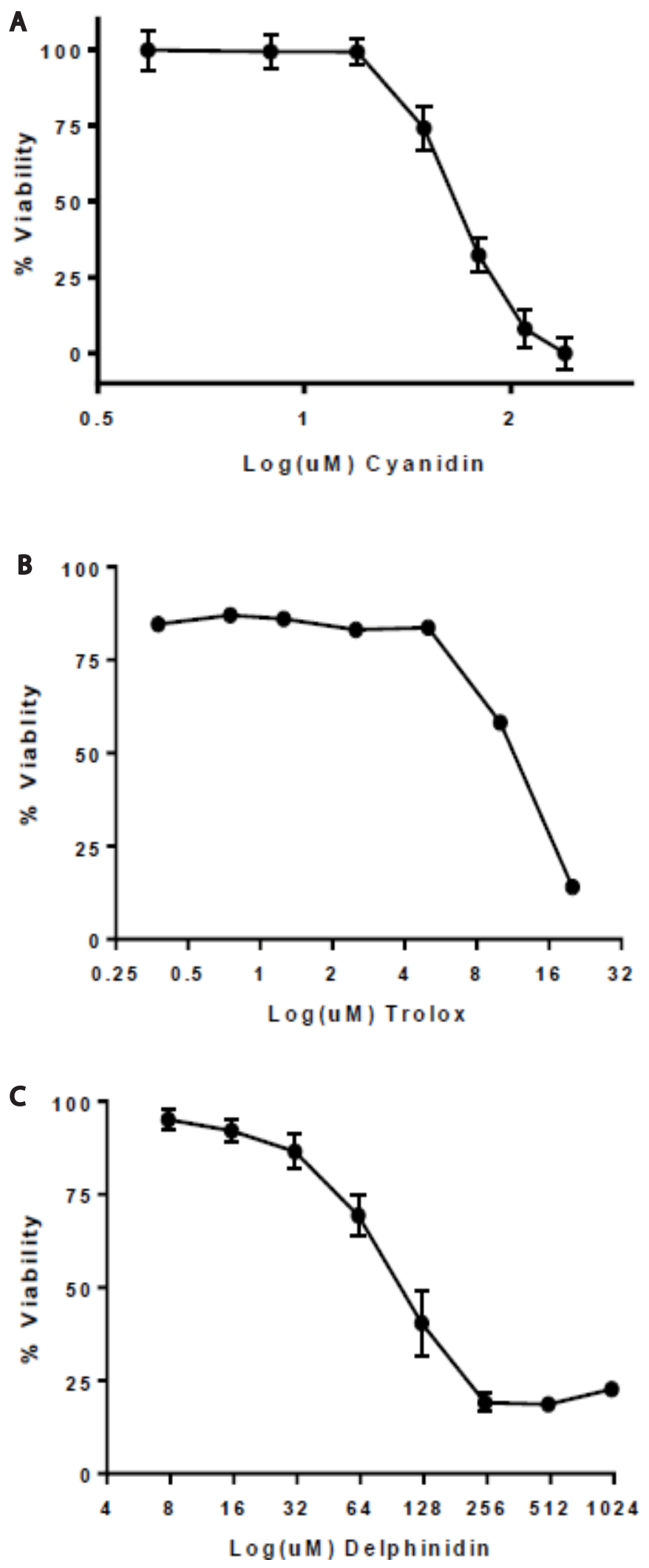

Figure 2. Proliferation of MCF7 cells exposed to delphinidin, cyanidin, and Trolox. SRB stained MCF7 cells were measured at $490 \mathrm{~nm}$ after exposure to (A) Delphinidin, (B) Cyanidin, and (C) Trolox after $24 \mathrm{~h}$. Percent inhibition is shown and the estimated $\mathrm{IC}_{50}$ values for delphinidin, cyanidin, and Trolox were $120 \mu \mathrm{M}, 47.18 \mu \mathrm{M}$, and $11.25 \mu \mathrm{M}$, respectively. 



Figure 3. Cell images taken at varying concentrations of delphinidin, cyanidin, and Trolox. Effect of delphinidin, cyanidin, and Trolox on microtubule, actin, and nuclear organization in MCF7 cells shown in immunofluorescence images of microtubules (green), actin (red), and DNA (blue) in fixed MCF7 cells after incubation in the absence or presence of delphinidin, cyanidin, or Trolox for 24 hours. A-D: Delphinidin - Control, $50 \mu \mathrm{M}, 75 \mu \mathrm{M}$, $100 \mu \mathrm{M}$; E-H: Cyanidin - Control, $62.5 \mu \mathrm{M}, 125 \mu \mathrm{M}, 250 \mu \mathrm{M}$; I-L: Trolox - Control, 1.25 $\mu \mathrm{M}, 5 \mu \mathrm{M}, 20 \mu \mathrm{M}$.

MCF7 human breast adenocarcinoma cells were used as a model to study the anticancer effects of commonly found anthocyanins in bilberry, delphinidin and cyanidin. In previous studies, the abundant amount of delphinidin and cyanidin in bilberry [15] inhibit cancer cell growth in vitro by various anthocyanin-containing extracts or purified anthocyanin fractions $[20,28,29]$.

Given that delphinidin and cyanidin are antioxidants, the free radical scavenging capability of delphinidin and cyanidin was compared with the scavenging effects of Trolox, a reference standard antioxidant, by DPPH antioxidant assay. Delphinidin and cyanidin were capable of scavenging DPPH radicals in a concentration-dependent manner as compared to control. The $\mathrm{IC}_{50}$ values for delphinidin, cyanidin, and Trolox were $80 \mu \mathrm{M}, 63 \mu \mathrm{M}, 1.30 \mu \mathrm{M}$, respectively (Figure 1). Cyanidin was more effective at scavenging DPPH radicals than delphinidin but Trolox was by far the most potent scavenger. Kähkönen et al. [6] reported a DPPH radical scavenging activity of $42 \mu \mathrm{M}, 33 \mu \mathrm{M}$, and 35 $\mu \mathrm{M}$ for delphinidin, cyanidin, and Trolox respectively. Tanaka et al. [30] also reported $32.3 \mu \mathrm{M}$ and $31.2 \mu \mathrm{M} \mathrm{DPPH} \mathrm{IC}{ }_{50}$ values for cyanidin and Trolox. The difference is seemingly negligible as Rice-Evens and colleagues report trihydroxylation of the $\mathrm{B}$ ring of cyanidin as in delphinidin neither enhances nor diminishes the Trolox equivalent antioxidant capacity [25]. The tremendous potency of Trolox, despite only having two hydroxyl groups, remains to be elucidated. In general, the DPPH assay results are in accordance with previous observations on the effect of hydroxylation and methoxylation in ring $\mathrm{B}$ to radical scavenging ability in aqueous phase [6].

To evaluate the anti-proliferative effects of delphinidin and cyanidin, SRB cytotoxicity assay was used to determine the $\mathrm{IC}_{50}$ values of these two anthocyanins. Cyanidin had a lower IC $_{50}$ value of 47.18 $\mu \mathrm{M}$ as compared to delphinidin with $120 \mu \mathrm{M}$ which correlates with the stronger radical scavenging capability of cyanidin as seen in the DPPH assay. In addition, Trolox had the lowest $\mathrm{IC}_{50}$ value of 11.25 $\mu \mathrm{M}$ also correlating to the DPPH assay findings. Previous studies have proven that natural food colors and anthocyanins show a dosedependence growth inhibition against breast, colon, stomach, central nervous system, and lung tumor cells $[16,31,32]$. Future studies include treating normal breast cells with delphinidin and cyanidin to discover whether the cytotoxic effects are specific to breast cancer cells. Zhao and coworkers demonstrated anthocyanin-rich extracts inhibit cancer but not normal colon cell growth [32]. Additionally, shedding light on the cellular mechanistic uptake and bioavailability of anthocyanins [33] is extremely important due to how the substitution pattern of anthocyanidins affects cell proliferation signaling cascades [34,35] and perhaps are as potent inhibitors of the epidermal growth factor receptor [20].

Concurrent with our previously published bilberry extract study, delphinidin and cyanidin at high concentrations caused depolymerization of tubulin and actin with rounding cell bodies and condensed nuclei as shown by immunofluorescence microscopy. Parallel to the DPPH and SRB assay findings, a low concentration of Trolox $(5 \mu \mathrm{M})$, exhibited significant damage to microtubules. This is the first report to our knowledge that observes the effects of delphinidin and cyanidin on MCF7 microtubule and actin structures in cells.

Overall, delphinidin, cyanidin, and Trolox were able to effectively scavenge DPPH free radicals, inhibit MCF7 cell growth, and induce characteristic apoptotic features as seen in the immunofluorescence images. Strikingly, Trolox, with only 2 hydroxyl groups on its structure, was able to scavenge DPPH radicals, inhibit cell growth, and cause apoptosis at much lower concentrations than delphinidin and cyanidin, who have 6 and 5 hydroxyl groups, respectively. The purpose of these experiments was to elucidate whether anthocyanins, as antioxidants, were the key mechanism in causing cytotoxicity in MCF7 breast cancer cells. Trolox, a vitamin $\mathrm{E}$ derivative and an antioxidant, was more effective at inducing cytotoxic effects on the cells leading us to think anthocyanins like delphinidin and cyanidin may cause apoptosis in MCF7 cells through a different mechanism than Trolox. Future studies to examine the mechanism of action of delphinidin and cyanidin include elucidating biochemical features such as activation of proapoptotic Bcl-2 family proteins, activation of caspases, mitochondrial membrane potential, oglionucleosomal fragmentation, plasma membrane rupture, and ROS over-generation.

\section{Authorship and contributorship}

Conception and design: Jessica Tang, Emin Oroudjev, George Ayoub, Leslie Wilson.

Development of methodology: Jessica Tang, Emin Oroudjev, George Ayoub, Leslie Wilson

Acquisition of data: Jessica Tang. Analysis and interpretation of data: Jessica Tang, Emin Oroudjev, George Ayoub. Writing, review, and/or revisions of the manuscript: Jessica Tang, George Ayoub. Study supervision: George Ayoub, Leslie Wilson. 


\section{Acknowledgment}

The technical assistance of Catherine Zheng and Breanna Duplisea is gratefully acknowledged. The use of cyanins in sunscreen applicationsis covered by U.S. Patent $6,783,754$. The contact for licensing opportunities is: Roy Mankovitz, Director, Montecito Wellness LLC, 1482 East Valley Rd, Suite 808, Santa Barbara, CA 93108, USA, 1-805-969-4604.

\section{Funding}

This work was supported by the Santa Barbara Cottage Hospital Research Grant Program, UC Santa Barbara Undergraduate Research and Creative Activities Grant (\#S3993), and Mr. Roy Mankovitz for providing the funding for this study.

\section{References}

1. Prior RL, Cao G, Martin A, Sofic E, McEven J, et al. (1998) Antioxidant capacity as influenced by total phenolic and anthocyanin content, maturity, and variety of Vaccinium species. J Agri Food Chem 46: 2686-2693.

2. Burdulis D, Ivanauskas L, Dirse V, Kazlauskas S, Razukas A (2007) Study of diversity of anthocyanin composition in bilberry (Vaccinium myrtillus L.) fruits. Medicina (Kaunas) 43: 971-977. [Crossref]

3. Hou DX, Kai K, Li JJ, Lin S, Terahara N, et al. (2004) Anthocyanidins inhibit activator protein 1 activity and cell transformation: structure-activity relationship and molecular mechanisms. Carcinogenesis 25: 29-36. [Crossref]

4. Zafra-Stone S, Yasmin T, Bagchi M, Chatterjee A, Vinson JA, et al. (2007) Berry anthocyanins as novel antioxidants in human health and disease prevention. Mol Nutr Food Res 51: 675-683. [Crossref]

5. Kuntz S, Wenzel U, Daniel H (1999) Comparative analysis of the effects of flavonoids on proliferation, cytotoxicity, and apoptosis in human colon cancer cell lines. Eur J Nutr 38: 133-142. [Crossref]

6. Kähkönen MP, Hopia AI, Heinonen M (2001) Berry phenolics and their antioxidant activity. J Agric Food Chem 49: 4076-4082. [Crossref]

7. Kong JM, Chia LS, Goh NK, Chia TF, Brouillard R (2003) Analysis and biological activities of anthocyanins. Phytochemistry 64: 923-933. [Crossref]

8. Lazzé MC, Pizzala R, Savio M, Stivala LA, Prosperi E, et al. (2003) Anthocyanins protect against DNA damage induced by tert-butyl-hydroperoxide in rat smooth muscle and hepatoma cells. Mutation Res 535: 103-115. [Crossref]

9. Seeram NP, Bourquin LD, Nair MG (2001) Degradation products of cyanidin glycosides from tart cherries and their bioactivities. J Agric Food Chem 49: 4924-4929. [Crossref]

10. Tsuda T, Horio F, Kitoh J, Osawa T (1999) Protective Effects of Dietary Cyanidin 3-ObD-Glucoside on Liver Ischemia-Reperfusion Injury in Rats. Arch Biochem Biophys 368: 361-366. [Crossref]

11. Tsuda T, Kato Y, Osawa T (2000) Mechanism for the peroxynitrite scavenging activity by anthocyanins. FEBS Lett 484: 207-210. [Crossref]

12. Tsuda T, Shiga K, Ohshima K, Kawakishi S, Osawa T (1996) Inhibition of lipid peroxidation and the active oxygen radical scavenging effect of anthocyanin pigments isolated from Phaseolus vulgaris L. Biochem Pharmacol 52: 1033-1039. [Crossref]

13. Subarnas A, Wagner H (2000) Analgesic and anti-inflammatory activity of the proanthocyanidin shellegueain A from Polypodium feei METT. Phytomedicine 7: 401405. [Crossref]

14. Lazzè MC, Savio M, Pizzala R, Cazzalini O, Perucca P, et al. (2004) Anthocyanins induce cell cycle perturbations and apoptosis in different human cell lines. Carcinogenesis 25: 1427-1433. [Crossref]

15. Nakajima JI, Tanaka I, Seo S, Yamazaki M, Saito K (2004) LC/PDA/ESI-MS Profiling and Radical Scavenging Activity of Anthocyanins in Various Berries. J Biomed Biotechnol 2004: 241-247. [Crossref]

16. Reddy MK, Alexander-Lindo RL, Nair MG (2005) Relative inhibition of lipid peroxidation, cyclooxygenase enzymes, and human tumor cell proliferation by natural food colors. J Agri Food Chem 53: 9268-9273. [Crossref]

17. Iwashita K, Kobori M, Yamaki K, Tsushida T (2000) Flavonoids inhibit cell growth and induce apoptosis in B16 melanoma 4A5 cells. Biosci Biotechnol Biochem 64: 18131820. [Crossref]

18. Nesaretnam K, Ambra R, Selvaduray KR, Radhakrishnan A, Reimann K, et al. (2004) Tocotrienol-rich fraction from palm oil affects gene expression in tumors resulting from MCF-7 cell inoculation in athymic mice. Lipids 39: 459-467. [Crossref]

19. Seeram NP (2008) Berry fruits for cancer prevention: current status and future prospects. J Agric Food Chem 56: 630-635. [Crossref]

20. Meiers S, Kemény M, Weyand U, Gastpar R, von Angerer E, et al. (2001) The anthocyanidins cyanidin and delphinidin are potent inhibitors of the epidermal growthfactor receptor. J Agric Food Chem 49: 958-962. [Crossref]

21. Chang YC, Huang HP, Hsu JD, Yang SF, Wang CJ (2005) Hibiscus anthocyanins rich extract-induced apoptotic cell death in human promyelocytic leukemia cells. Toxicol Appl Pharmacol 205: 201-212. [Crossref]

22. Seeram NP, Adams LS, Zhang Y, Lee R, Sand D, et al. (2006) Blackberry, black raspberry, blueberry, cranberry, red raspberry, and strawberry extracts inhibit growth and stimulate apoptosis of human cancer cells in vitro. J Agri Food Chem 54: 93299339. [Crossref]

23. Shih PH, Yeh CT, Yen GC (2005) Effects of anthocyanidin on the inhibition of proliferation and induction of apoptosis in human gastric adenocarcinoma cells. Food Chem Toxicol 43: 1557-1566. [Crossref]

24. Zhang Y, Vareed SK, Nair MG (2005) Human tumor cell growth inhibition by nontoxic anthocyanidins, the pigments in fruits and vegetables. Life Sci 76: 1465-1472. [Crossref]

25. Rice-Evans CA, Packer L (2004) Flavonoids in health and disease. CRC Press.

26. Nguyen V, Tang J, Oroudjev E, Lee CJ, Marasigan C, et al. (2010) Cytotoxic effects of bilberry extract on MCF7-GFP-tubulin breast cancer cells. J Med Food 13: 278-285. [Crossref]

27. Panda D, Jordan MA, Chu KC, Wilson L (1996) Differential effects of vinblastine on polymerization and dynamics at opposite microtubule ends. J Biol Chem 271: 29807 29812. [Crossref]

28. Katsube N, Iwashita K, Tsushida T, Yamaki K, Kobori M (2003) Induction of apoptosis in cancer cells by Bilberry (Vaccinium myrtillus) and the anthocyanins. J Agric Food Chem 51: 68-75. [Crossref]

29. Eskra JN, Schlicht MJ, Bosland MC (2014) Effects of black raspberries and their constituents on rat prostate carcinogenesis and human prostate cancer cell growth Cancer Res 74: 2131-2131.

30. Tanaka J, Nakanishi T, Ogawa K, Tsuruma K, Shimazawa M, et al. (2011) Purple rice extract and anthocyanidins of the constituents protect against light-induced retinal damage in vitro and in vivo. J Agric Food Chem 59: 528-536. [Crossref]

31. Kamei H, Kojima T, Hasegawa M, Koide T, Umeda T, et al. (1995) Suppression of tumor cell growth by anthocyanins in vitro. Cancer Invest 13: 590-594. [Crossref]

32. Zhao C, Giusti MM, Malik M, Moyer MP, Magnuson BA (2004) Effects of commercial anthocyanin-rich extracts on colonic cancer and nontumorigenic colonic cell growth. $J$ Agric Food Chem 52: 6122-6128. [Crossref]

33. Fang J (2014) Bioavailability of anthocyanins. Drug Metab Rev 46: 508-520. [Crossref]

34. Im NK, Jang WJ, Jeong CH, Jeong GS (2014) Delphinidin suppresses PMA-induced MMP-9 expression by blocking the NF-I ${ }^{\circ} \mathrm{B}$ activation through MAPK signaling pathways in MCF-7 human breast carcinoma cells. J Med Food 17: 855-861. [Crossref]

35. Sehitoglu MH, Farooqi AA, Qureshi MZ, Butt G, Aras A (2014) Anthocyanins: targeting of signaling networks in cancer cells. Asian Pac J Cancer Prev 15: 23792381. [Crossref]

Copyright: (C) 2015 Jessica Tang. This is an open-access article distributed under the terms of the Creative Commons Attribution License, which permits unrestricted use, distribution, and reproduction in any medium, provided the original author and source are credited. 